\title{
A retrospective study of oral and maxillofacial pathology lesions diagnosed at the Faculty of Dentistry, King Abdulaziz University
}

This article was published in the following Dove Medical Press journal: Clinical, Cosmetic and Investigational Dentistry

\author{
Nada A Alhindi \\ Amal M Sindi \\ Nada O Binmadi \\ Wael Y Elias
}

Oral Diagnostic Science Department, Faculty of Dentistry, King Abdulaziz University, Jeddah, Saudi Arabia
Correspondence: Nada Alhindi Oral Diagnostic Science Department, Faculty of Dentistry, King Abdulaziz University, PO Box 80209, Jeddah 21589 , Saudi Arabia

Tel +9660505376952

Email nalhendi@kau.edu.sa
Background: Oral and maxillofacial lesions (OMFL) comprise a broad spectrum of benign and malignant lesions that affect the oral cavity. However, few epidemiological studies have evaluated oral cavity lesions, and very few have focused on oral soft tissue pathology. The purpose of this study was to identify the prevalence and distribution of OMFL that had been diagnosed histologically at the Oral Pathology Laboratory, Faculty of Dentistry, King Abdulaziz University. Materials and methods: A retrospective study was conducted to assess the distribution of OMFL among the oral cavity biopsies submitted to the Oral Pathology Laboratory during the period from 1996 to 2016. Information on sex, age, location of the lesion, and histopathologic diagnosis was analyzed.

Results: A total of 1,218 cases were examined. Among these, reactive/adaptive lesions were the most common type $(\mathrm{n}=245 ; 20.1 \%)$ and cystic lesions were the second most common $(n=214 ; 17.6 \%)$, followed by inflammatory lesions $(n=152 ; 12.5 \%)$ and epithelial pathology $(\mathrm{n}=115 ; 9.4 \%)$.

Conclusion: The results of the present study provide valuable information on the prevalence of OMFL in Jeddah, Saudi Arabia. Reactive conditions were the most frequently diagnosed pathologies. Most oral and maxillofacial biopsies were soft tissue lesions, benign in nature, and inflammatory in origin. Further studies are necessary to provide more information on head and neck diseases in the general population to develop better future oral health policies.

Keywords: oral and maxillofacial pathology, Saudi Arabia, Jeddah, oral lesions

\section{Background}

Histopathologic analysis of biopsied specimens is an important essential diagnostic tool that is generally influenced by clinical data and other diagnostic tests. Assessing the distribution of oral and maxillofacial lesions (OMFL) is important for evaluating their prevalence in the population, and thus identifying high-risk subpopulations and optimizing health care service allocation. ${ }^{1}$ Also, knowledge of the site, age, and sex predilections of different diseases of the oral cavity is useful with regard to determining their demographics. ${ }^{2}$ Only few epidemiological studies on the frequency of histologically confirmed oral lesions have been conducted, primarily in the USA, India, some Asian nations, and Europe..$^{2-7}$ With regard to epidemiological data on oral lesions in the western region of Saudi Arabia, studies are limited, and the only published study is associated with the epidemiological outline of adolescent and pediatric lesions in the head and neck region among the population of the city of Jeddah. ${ }^{8}$ Andreasen et $\mathrm{al}^{9}$ reported that oral mucosal disease affects between $25 \%$ and $50 \%$ of individuals, 
depending on the population studied. This indicates the relatively high incidence of oral diseases in societies and necessitates intervention by local authorities to target these diseases in their communities. Therefore, the incidence and demographic characteristics of oral diseases and the oral health care needs of the population in our community should be investigated in order to develop a coherent oral health policy. In addition, such information could be useful for epidemiological and teaching purposes. The present retrospective study was conducted to describe oral lesions among 1,218 biopsies and to assess their demographic distribution in regards of age and sex. These biopsies were processed by the Oral Pathology Laboratory, Faculty of Dentistry, King Abdulaziz University, over a 20-year period.

\section{Materials and methods}

This was a retrospective study analyzing the archives of the Oral Pathology Laboratory, Faculty of Dentistry, King Abdulaziz University, Jeddah, Saudi Arabia. Data from 1,218 specimens recorded between 1996 and 2016 were retrieved from the laboratory's files, and information on sex, age, location of the lesion, and the histopathologic diagnosis were collated into a dataset and analyzed. Slides were reviewed in a blinded manner, without the reviewers knowing the original diagnoses, by two American board-certified oral and maxillofacial pathologists (NB and WE). Cases with discrepancies in diagnosis were re-examined and a consensus diagnosis was achieved. The Research Ethics Committee of the Faculty of Dentistry at King Abudulaziz University approved the study (Proposal No. 107-12-17).

Based on histologic findings obtained from the records, lesions were classified as adaptive/reactive lesions, cysts of the head and neck, bone lesions, odontogenic tumors, epithelial disorders, oral inflammation/infections, benign mesenchymal tumors, malignant tumors, immune-mediated diseases, tooth abnormalities, and salivary gland diseases. The classifications were adapted from Barnes ${ }^{10}$ and Bezroukov. ${ }^{11}$ Cases with inconclusive pathologic diagnoses were classified as miscellaneous.

Statistical data analysis was carried out using SPSS version 22 software. Descriptive statistics were used to outline the characteristics of the study categorical and nominal variables in the form of counts and percentages, whereas mean and SDs were determined for continuous variables.

\section{Results}

A total of 1,218 histologic diagnoses over a 20-year period were analyzed in this retrospective study, with 643 (52.8\%) derived from female subjects and 515 (42.3\%) derived from male subjects (a female to male ratio of about 1.3). Sex was not recorded in $60(4.9 \%)$ cases. The age of the patients ranged from 5 months to 85 years, and the mean age was 35.9 ( $\mathrm{SD} \pm 17.9$ years). Table 1 shows the occurrence of oral lesions according to demographic factors.

Of the 1,218 diagnosed cases, $765(62.8 \%)$ were soft tissue lesions and 453 (37.2\%) were hard tissue lesions. Reactive/adaptive lesions were the most common (245; $20.1 \%$ ), followed by cystic lesions $(214 ; 17.6 \%)$, inflammatory/infectious lesions (152; 12.5\%), epithelial lesions (115; $9.4 \%)$, benign mesenchymal tumors $(106 ; 8.7 \%)$, malignant tumors $(70 ; 5.7 \%)$, both immune-mediated diseases and salivary gland diseases and tumors $(60 ; 4.9 \%)$, odontogenic tumors $(45 ; 3.7 \%)$, bone lesions $(30 ; 2.5 \%)$, pigmented lesions $(16 ; 1.3 \%)$, and tooth abnormalities $(12 ; 1 \%)$. Ninetythree $(7.6 \%)$ miscellaneous cases had inconclusive pathologic diagnoses or were without recorded pathologic alterations. Figure 1 shows the percentage distribution of all OMFL by categories, while Table 2 shows the distribution of all categories by number, age mean, and range.

In all categories, prevalence of oral and maxillofacial pathology lesion (OMFPL) in female was higher than that in male, except malignant tumors $(n=39 / 70)$, epithelial lesions $(n=62 / 115)$, odontogenic tumors $(n=25 / 45)$, and teeth abnormalities $(n=8 / 12)$, as illustrated in Figure 2.

Fibroepithelial polyp was the most common lesion in the reactive group $(n=65 ; 26.5 \%)$. Inflammatory odontogenic cyst (radicular cyst) was the most common diagnosis among all cystic types in the oral and maxillofacial area $(n=134$; $62.6 \%$ ), while periapical granuloma was the most common inflammatory condition ( $\mathrm{n}=115 ; 75.7 \%)$. In the benign tumor category, fibroma was the most frequently diagnosed condition $(n=75 ; 70.8 \%)$. On the other hand, malignant lesions constituted 70/1,218 (5.8\%) cases, of which squamous cell carcinoma (SCC) was the most frequent malignancy $(n=46$; $65.7 \%$ ). The frequencies of other histopathologic diagnoses and their age and sex distributions are shown in Table 3.

Table I Demographic patient data

\begin{tabular}{|l|l|l|l|l|l|}
\hline Variables & Number & Minimum & Maximum & Mean & SD \\
\hline Age & $\mathrm{I}, 218$ & 5 months & 85 years & $\begin{array}{l}35.9 \\
\text { years }\end{array}$ & $\begin{array}{l}17.9 \\
\text { years }\end{array}$ \\
\hline \multicolumn{3}{|l|}{} & Count & $\%$ \\
\hline \multirow{3}{*}{ Sex } & Total & 1,218 & 100.0 \\
\cline { 2 - 5 } & Male & 515 & 42.3 \\
\cline { 2 - 5 } & Female & 643 & 52.8 \\
\cline { 2 - 5 } & Unidentified & 60 & 4.9 \\
\hline
\end{tabular}




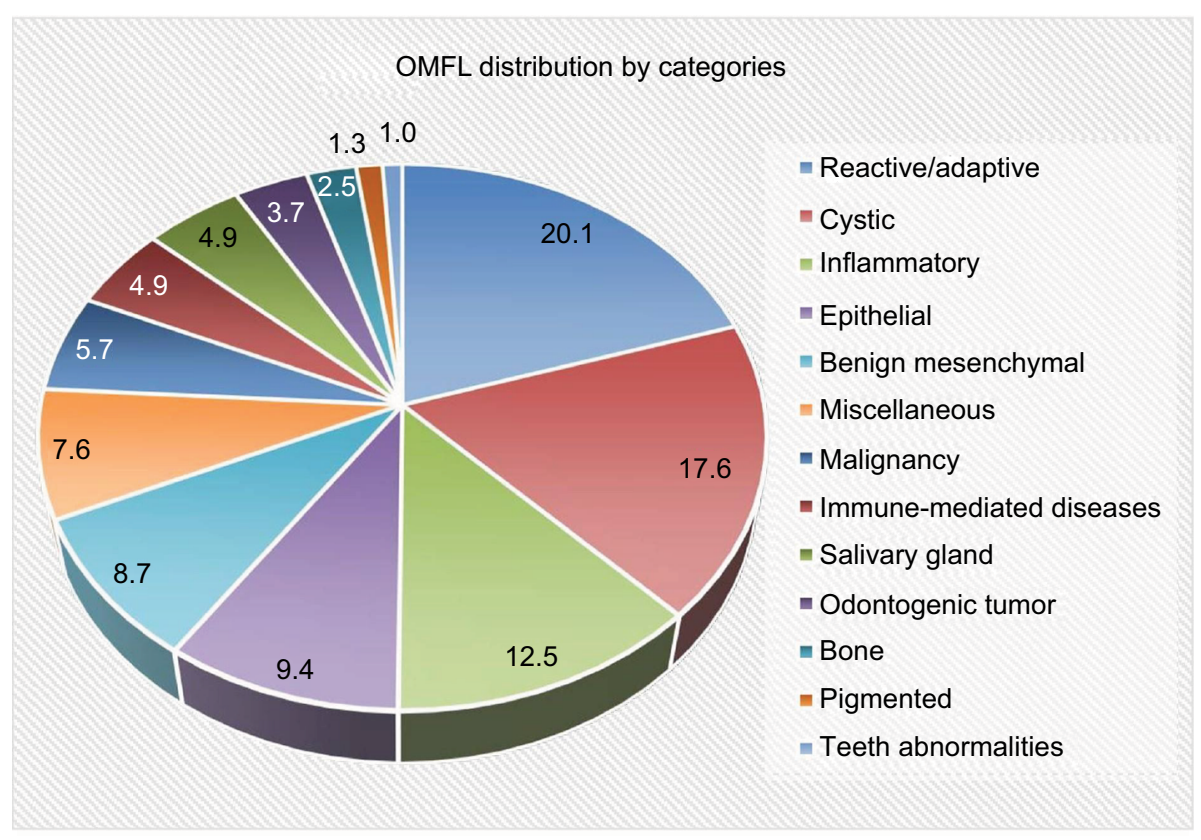

Figure I The categories of OMFL and their percentage distribution.

Abbreviation: OMFL, oral and maxillofacial lesions.

Table 2 Number of diagnoses by category (1996-2016)

\begin{tabular}{|c|c|c|c|c|}
\hline Diagnostic category & Number of cases & $\begin{array}{l}\text { Mean } \\
\text { age }\end{array}$ & SD & Age range (years) \\
\hline Reactive/adaptive $^{\mathrm{a}}$ & 245 & 37.16 & 17.4 & $5-85$ \\
\hline Cystic $^{\mathrm{a}}$ & 214 & 31.83 & 15.4 & $5-85$ \\
\hline Inflammatory ${ }^{\mathrm{a}}$ & 152 & 31.48 & 15.6 & $6-75$ \\
\hline Epithelial lesions ${ }^{\mathrm{a}}$ & 115 & 44.08 & 17.4 & $5-84$ \\
\hline Benign mesenchymal tumors ${ }^{\mathrm{a}}$ & 106 & 41.35 & 19.1 & 5 months -77 years \\
\hline Miscellaneous $^{\mathrm{a}}$ & 93 & 30.6 & 22.0 & $4-72$ \\
\hline Malignant tumors & 70 & 49.52 & 20.7 & $2-85$ \\
\hline 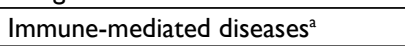 & 60 & 44.38 & 13.0 & $16-62$ \\
\hline Salivary gland diseases and tumors & 60 & 27.30 & 16.2 & $5-65$ \\
\hline Odontogenic tumors ${ }^{\mathrm{a}}$ & 45 & 25.46 & 14.8 & $9-68$ \\
\hline Bone $^{\mathrm{a}}$ & 30 & 31.25 & 19.9 & $2.5-81$ \\
\hline Pigmented ${ }^{\mathrm{a}}$ & 16 & 37.13 & 13.6 & $19-65$ \\
\hline Tooth abnormalities & 12 & 23.25 & $1 \mathrm{I} .4$ & $9-41$ \\
\hline Total & 1,218 & & & \\
\hline
\end{tabular}

Note: aSex of some patients was unknown.

\section{Discussion}

Over 20 years, the overall number of OMFPL recorded was 1,218 . The reasons for the low number of biopsies from the oral and maxillofacial region may include high dependence on clinical diagnosis and the fact that the laboratory was at an academic teaching center whereas most of the cases were referred to hospitals due to logistic considerations that restricted the reception of several cases. Also, governmental hospitals were the only external sources of cases. ${ }^{3,12}$ Previous studies performed in Saudi Arabia were limited and either focused on a specific age group such as children ${ }^{8}$ or geriatric patients ${ }^{13}$ or on specific entities such as odontogenic tumors. ${ }^{14}$ Only two published studies have investigated the prevalence of OMFPLs in both northern and south western regions of Saudi Arabia. ${ }^{15,16}$

Our data demonstrated a higher prevalence of OMFPL in female subjects (52.8\%), and this trend has been reported in other studies. The possible explanation of this pertains to women utilizing health care more than men., ${ }^{3,17-19}$ However, our data differ from those of other studies reporting a high 


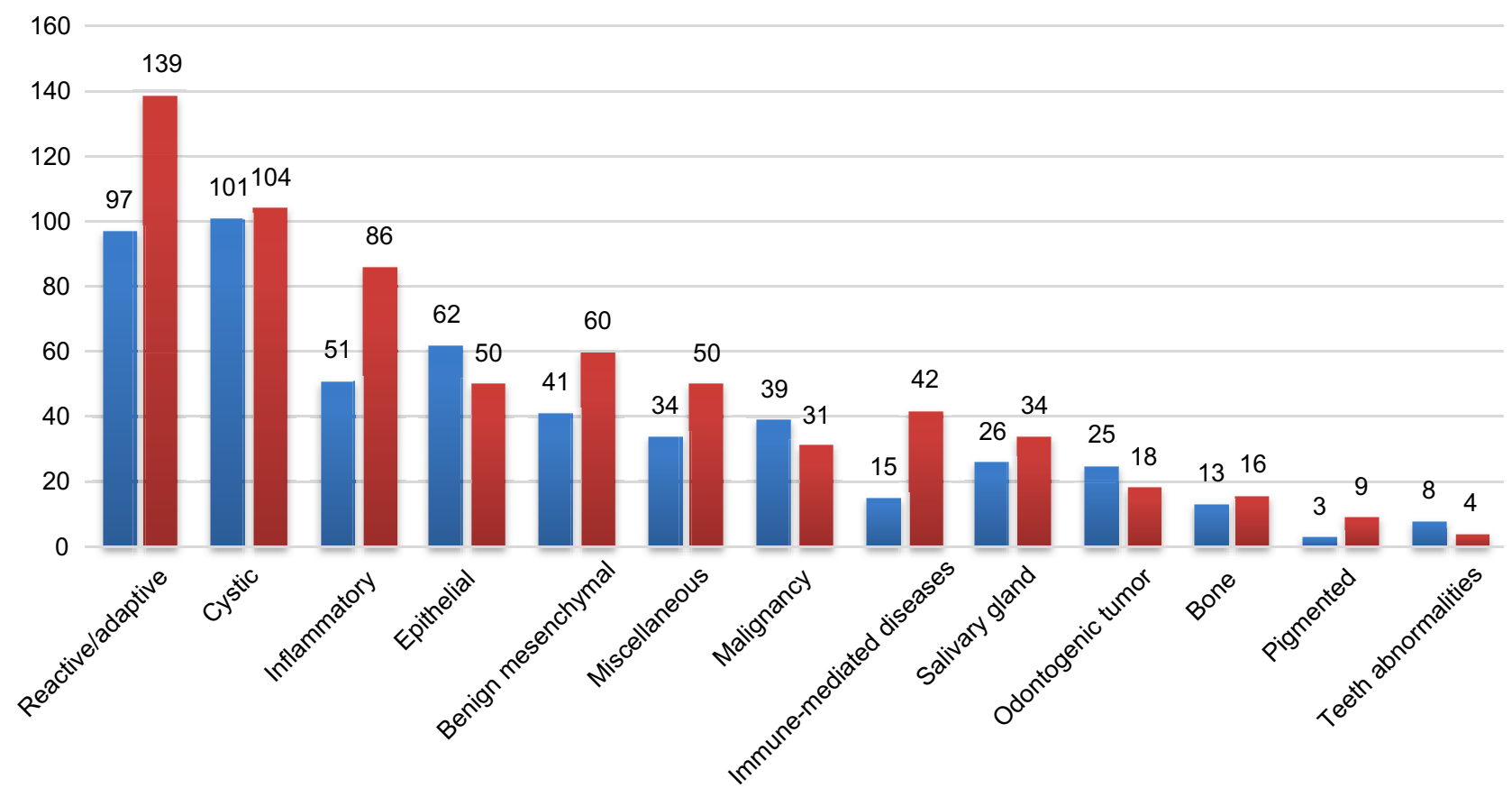

Figure 2 The distribution of gender among OMFL.

Abbreviation: OMFL, oral and maxillofacial lesions.

Table 3 Histopathologic diagnoses in each category

\begin{tabular}{|c|c|c|c|c|c|c|}
\hline Diagnosis & Number & Male & Female & $\begin{array}{l}\text { M:F } \\
\text { ratio }\end{array}$ & $\begin{array}{l}\text { Mean age } \\
\text { (years) }\end{array}$ & SD \\
\hline Reactive/adaptive & 245 & & & & & \\
\hline Fibroepithelial polyp ${ }^{a}$ & 65 & 19 & 42 & 0.45 & 41.70 & 16.93 \\
\hline Pyogenic granuloma ${ }^{a}$ & 63 & 29 & 33 & 0.88 & 34.45 & 16.91 \\
\hline Nonspecific inflammation ${ }^{a}$ & 58 & 29 & 26 & 1.12 & 37.49 & 17.78 \\
\hline Scar and fibrosis ${ }^{a}$ & 26 & 9 & 16 & 0.56 & 35.88 & 16.00 \\
\hline Inflammatory fibrous hyperplasia ${ }^{a}$ & 14 & 5 & 8 & 0.57 & 43.21 & 21.93 \\
\hline Peripheral ossifying fibroma & 5 & 3 & 4 & 0.75 & 34.20 & 14.92 \\
\hline Plasma cell gingivitis ${ }^{\mathbf{a}}$ & 5 & 0 & 4 & 0 & 33.50 & 9.26 \\
\hline Gingival polyp & 3 & 0 & 3 & 0 & 14.33 & 2.52 \\
\hline Peripheral giant cell granuloma & 3 & 1 & 2 & 0.50 & 47.00 & 19.80 \\
\hline Hamartoma & I & 1 & 0 & & 49 & 0 \\
\hline Xanthogranuloma & I & I & 0 & & 27 & 0 \\
\hline Submucous fibrosis & 1 & 0 & $\mathrm{I}$ & 0 & 45 & 0 \\
\hline Cystic & 214 & & & & & \\
\hline \multicolumn{7}{|l|}{ Inflammatory odontogenic cyst } \\
\hline Radicular and residual cysts & 134 & 65 & 62 & 1.0 & 32.1 & 14.6 \\
\hline \multicolumn{7}{|l|}{ Developmental odontogenic cyst } \\
\hline Dentigerous cyst & 38 & 19 & 17 & I.I & 28.2 & 13.5 \\
\hline Odontogenic keratocyst & 17 & 9 & 8 & I.I & 35.8 & 16.4 \\
\hline Gorlin cyst & 2 & 0 & 2 & 0.0 & 20.5 & 7.8 \\
\hline Glandular odontogenic cyst & 3 & 1 & 2 & 0.5 & 71.5 & 19.1 \\
\hline Lateral periodontal cyst & I & 0 & 1 & 0 & 35.0 & 0 \\
\hline \multicolumn{7}{|l|}{ Non-odontogenic cyst } \\
\hline Traumatic bone cyst & 7 & 2 & 5 & 0.4 & 38.4 & 16.41 \\
\hline Antral cyst & 3 & 1 & 2 & 0.5 & 34 & 1.73 \\
\hline Nasolabial cyst & 2 & 0 & 2 & 0 & $4 I$ & 11.31 \\
\hline
\end{tabular}

(Continued) 
Table 3 (Continued)

\begin{tabular}{|c|c|c|c|c|c|c|}
\hline Diagnosis & Number & Male & Female & $\begin{array}{l}\text { M:F } \\
\text { ratio }\end{array}$ & $\begin{array}{l}\text { Mean age } \\
\text { (years) }\end{array}$ & SD \\
\hline Oral lymphoepithelial cyst & 2 & 1 & I & I & 49 & 2.83 \\
\hline Median palatal cyst & I & 1 & 0 & & 24 & 0 \\
\hline Sebaceous cyst & I & 1 & 0 & & 52 & 0 \\
\hline Thyroglossal tract cyst & I & 0 & I & 0 & 13 & 0 \\
\hline Dermoid cyst & 1 & 0 & I & 0 & 25 & 0 \\
\hline Nasopalatine duct cyst & 1 & $\mathrm{I}$ & 0 & & 55 & 0 \\
\hline Inflammatory & 152 & & & & & \\
\hline Periapical granuloma or abscess ${ }^{a}$ & 115 & 37 & 63 & 0.59 & 31.10 & 14.56 \\
\hline Pulp diseases & 14 & 4 & 10 & 0.40 & 22 & 14.43 \\
\hline Osteomyelitis & 10 & 4 & 6 & 0.67 & 47.22 & 21.05 \\
\hline Infectious conditions & 7 & 2 & 5 & 0.40 & 35.67 & 9.93 \\
\hline Sinus conditions & 6 & 4 & 2 & 2.00 & 31.83 & 14.08 \\
\hline Epithelial & 115 & & & & & \\
\hline Hyperkeratosis and acanthosis ${ }^{\mathrm{a}}$ & 66 & 36 & 27 & 1.33 & 45.09 & 15.62 \\
\hline Epithelial dysplasia & 31 & 16 & 15 & 1.07 & 53.71 & 15.05 \\
\hline Papilloma & 14 & 7 & 7 & 1 & 19.50 & 14.54 \\
\hline Smokeless tobacco lesion & 3 & 3 & 0 & & 42 & 12.17 \\
\hline Verruca vulgaris & 1 & 0 & $\mathrm{I}$ & 0 & 14 & 0 \\
\hline Benign mesenchymal & 106 & & & & & \\
\hline Fibroma & 75 & 27 & 43 & 0.63 & 44.97 & 16.33 \\
\hline Vascular tumor & 7 & 5 & 2 & 2.50 & 35.67 & 26.85 \\
\hline Lipoma & 6 & I & 5 & 0.20 & 50.50 & 13.20 \\
\hline Leiomyoma & 3 & I & 2 & 0.50 & 11.33 & 8.39 \\
\hline Neurofibroma & 4 & I & 3 & 0.33 & 31.75 & 20.84 \\
\hline Fibrous histiocytoma & 3 & I & 2 & 0.50 & 28.33 & 10.12 \\
\hline Teratoma & I & 0 & I & 0 & 5 months & 0 \\
\hline Myofibroma & I & I & 0 & & 4 & 0 \\
\hline Osteoma & 1 & I & 0 & & 20 & 0 \\
\hline Inflammatory myofibroblastic tumor & 1 & 0 & 1 & 0 & 10 & 0 \\
\hline Traumatic neuroma & I & 0 & I & 0 & & \\
\hline Plasma cell myeloma & 1 & I & 0 & & 66 & 0 \\
\hline Granular cell tumor & I & I & 0 & & 48 & 0 \\
\hline Myxoma & 1 & I & 0 & & 42 & 0 \\
\hline Malignancies & 70 & & & & & \\
\hline Squamous cell carcinoma & 46 & 27 & 19 & 1.42 & 56.65 & 16.62 \\
\hline Langerhans cell histiocytosis & 10 & 7 & 3 & 2.33 & 32.60 & 17 \\
\hline Verrucous carcinoma & 4 & 2 & 2 & 1 & 67.75 & 8.99 \\
\hline Lymphoma & 3 & 0 & 3 & 0 & 41.67 & 21.50 \\
\hline Nasopharyngeal carcinoma & I & 0 & I & 0 & 76 & 0 \\
\hline Fibrosarcoma & I & I & 0 & & 17 & 0 \\
\hline Round blue cell sarcoma & I & 0 & 1 & 0 & 19 & 0 \\
\hline Osteosarcoma & I & 0 & 1 & 0 & 20 & 0 \\
\hline Pigmented neuroectodermal tumor of infancy & I & 1 & 0 & & 2 & 0 \\
\hline Rhabdomyosarcoma & I & 0 & $\mathrm{I}$ & 0 & 51 & 0 \\
\hline Undifferentiated neoplasm & I & I & 0 & & 40 & 0 \\
\hline Immune-mediated disease & 60 & & & & & \\
\hline Lichen planus $^{\mathrm{a}}$ & 54 & 12 & 39 & 0.31 & 44.70 & 12.96 \\
\hline Pemphigus & 6 & 3 & 3 & $\mathrm{I}$ & 42 & 14.28 \\
\hline Salivary gland & 60 & & & & & \\
\hline \multicolumn{7}{|l|}{ Malignant } \\
\hline Adenoid cystic adenocarcinoma & 3 & 2 & I & 2 & 48.67 & 8.49 \\
\hline Mucoepidermoid carcinoma & 2 & 0 & 2 & 0 & 45 & 14.14 \\
\hline Polymorphous low-grade adenocarcinoma & I & I & 0 & & 19 & 0 \\
\hline Carcinoma ex pleomorphic adenoma & I & 0 & I & 0 & 42 & 0 \\
\hline Adenocarcinoma not otherwise specified & I & 0 & 1 & 0 & 27 & 0 \\
\hline Basal cell adenocarcinoma & $\mathrm{I}$ & 0 & $\mathrm{I}$ & 0 & & \\
\hline
\end{tabular}


Table 3 (Continued)

\begin{tabular}{|c|c|c|c|c|c|c|}
\hline Diagnosis & Number & Male & Female & $\begin{array}{l}\text { M:F } \\
\text { ratio }\end{array}$ & $\begin{array}{l}\text { Mean age } \\
\text { (years) }\end{array}$ & SD \\
\hline \multicolumn{7}{|l|}{ Benign } \\
\hline Pleomorphic adenoma & 5 & 3 & 2 & 1.5 & 36.5 & 13.48 \\
\hline Warthin's tumor & I & I & 0 & & 53 & 0 \\
\hline \multicolumn{7}{|l|}{ Salivary gland diseases } \\
\hline Mucocele ${ }^{\mathrm{a}}$ & 34 & 16 & 19 & 0.84 & 18.59 & 10.88 \\
\hline Retention cyst $\mathrm{t}^{\mathrm{a}}$ & 3 & 0 & 2 & 0 & 56.67 & 34.21 \\
\hline Necrotizing sialometaplasia & 3 & 2 & I & 2 & 49.67 & 16.04 \\
\hline Ranula & 2 & 0 & 2 & 0 & 9 & 2.83 \\
\hline Sialolithiasis & I & 0 & I & 0 & 47 & 0 \\
\hline Chronic sialadenitis & I & 0 & I & 0 & 35 & 0 \\
\hline Chronic sclerosing polycystic adenosis & 1 & $\mathrm{I}$ & 0 & & 12 & 0 \\
\hline Odontogenic tumor & 45 & & & & & \\
\hline Ameloblastoma $^{\mathrm{a}}$ & 21 & 13 & 7 & 1.86 & 24.50 & 12.15 \\
\hline Odontoma $^{\mathrm{a}}$ & 17 & 9 & 7 & 1.29 & 23.07 & 15.06 \\
\hline Adenomatoid odontogenic tumor & 2 & I & I & I & 22.5 & 7.78 \\
\hline Ameloblastic fibroma & 2 & I & I & I & 22 & 7.07 \\
\hline Calcifying epithelial odontogenic tumor & 2 & 0 & 2 & 0 & 47 & 0 \\
\hline Ameloblastic carcinoma & I & I & 0 & 0 & 68 & 0 \\
\hline Bone & 30 & & & & & \\
\hline Benign fibro-osseous lesions ${ }^{\mathrm{a}}$ & 24 & 10 & 13 & 0.77 & 27.58 & 17.91 \\
\hline Giant cell lesions & 4 & 3 & I & 3 & 30 & 8.12 \\
\hline Osteonecrosis & 2 & 0 & 2 & 0 & 70.5 & 14.85 \\
\hline Pigmented & 16 & & & & & \\
\hline Nevus (intradermal/intercostal) & 7 & 2 & 2 & I & 32.14 & 7.88 \\
\hline Melanotic macule & 4 & 0 & 4 & 0 & 51.75 & 11.30 \\
\hline Racial pigmentation ${ }^{\mathrm{a}}$ & 2 & 0 & I & 0 & 19 & 0.00 \\
\hline Amalgam tattoo & 2 & I & I & I & 43 & $\mid 1.31$ \\
\hline Melanoacanthoma & 1 & 0 & $\mathrm{I}$ & 0 & 20 & 0 \\
\hline Teeth abnormalities & 12 & 8 & 4 & 2 & 23.25 & 11.41 \\
\hline Miscellaneous & 93 & 34 & 50 & 31.85 & 22.01 & 24.5 \\
\hline
\end{tabular}

Note: aUndetermined sex in some cases.

prevalence of OMFPL in male subjects in Saudi Arabia ${ }^{12,13}$ and other countries such as Kuwait and India. ${ }^{2,5}$ Specific lesions seemed to have a strong predilection for either sex. Male subjects exhibited greater incidences of malignant tumors (SCC), epithelial lesions (papilloma and epithelial dysplasia), and odontogenic tumors (ameloblastoma and odontoma), as shown in Figure 2, which is consistent with a study reported by Guedes et $\mathrm{al}^{7}$ in 2015 .

The age of oral lesion patients in the current study ranged from 5 months to 85 years, and most were in their third, fourth, or fifth decade of life, which is consistent with previous prevalence studies. ${ }^{15,18}$ Only malignant lesions were more common in more advanced age (mean age 49.5 years), with the highest peak in verrucous and SCCs (mean age 65.33 and 56.65 years, respectively), as has been previously reported with regard to oral cancers. ${ }^{2,12}$ On the other hand, patients with the lowest age were a 5-month-old infant with a teratoma and a 2-year-old boy with pigmented neuroectodermal tumor of infancy, which were classified as benign mesenchymal and malignant lesions, respectively. Teratomas presenting in the oropharyngeal region are usually diagnosed at birth or prenatally. ${ }^{20,21}$ Furthermore, the pigmented or melanotic neuroectodermal tumor of infancy are diagnosed mostly within the first year of life. ${ }^{22}$ Most of the OMFPLs were soft tissue lesions ( $n=765 ; 62.8 \%)$, as was also reported by Gambhir et al. ${ }^{2}$ This may reflect the preference of general practitioners, residents, and specialists to perform biopsies of extraosseous oral lesions by themselves and refer intraosseous oral lesion cases to oral maxillofacial surgeons.

The frequencies and types of OMFPL varied, but reactive/ adaptive lesions were the most common in the present study and several previous studies..$^{3,5,13,18}$ Fibroepithelial polyp was the most common diagnosis in this category (26.5\%), with a mean patient age of 41.7 years. A similar study showed the highest prevalence of traumatic fibroma (fibroepithelial polyp) among reactive lesions (37.4\%) mainly in patients 
in their third to fourth decade. ${ }^{23}$ Cystic lesions were the second most common, and the most prevalent inflammatory odontogenic cysts were radicular cysts in the current study, followed by dentigerous cysts as developmental odontogenic cysts, and this is concordant with Fierro-Garibay et al. ${ }^{24}$ In a study conducted in Saudi Arabia by Luqman and $\mathrm{Al}$ Shabab ${ }^{12}$ investigating inflammatory lesions - which were the third most common lesions diagnosed in our study - the majority of their 267 specimens were diagnosed as periapical granuloma. However, periapical granulomas were the second most common lesions diagnosed in our study, with 115 cases ( $9.4 \%$ of all specimens), and radicular cysts were the most commonly diagnosed inflammatory condition $(n=134 ; 11 \%)$, which was classified as cyst in our study.

Fibroma was the most common benign mesenchymal tumor, which is concordant with other studies. ${ }^{5,18}$ Lesions related to immune-mediated diseases were observed in 60 $(4.9 \%)$ specimens and were more common in female subjects $(70 \%)$, and the mean age of patients with these conditions was 44.4 years. In the present study, salivary gland lesions were grouped into salivary gland disease, benign and malignant tumors. Mucocele, pleomorphic adenoma, and adenoid cystic carcinoma were the most common diagnoses in each respective subgroup. The overall prevalences of immunemediated diseases and salivary gland lesions in this study were comparable to that of previous studies. ${ }^{4,15,17}$

The rate of malignant lesions in this study $(5.8 \%)$ was lower than the previously reported prevalence in Kuwait which reported only $6.5 \%$ of SCC. ${ }^{5}$ Surprisingly, studies from the south western region of Saudi Arabia reported a much higher incidence of malignant (38.8\%) compared to benign $(10.9 \%)$ neoplasms. ${ }^{16,25}$ This rise in malignancy was due to a major increase in SCC incidence (36.1\%) with a strong female predilection (F:M ratio $=1: 2.2$ ). Smokeless tobacco, specifically Shamma, was held accountable for this rise in SCC incidence in that region, as $>45 \%$ of SCC patients were Shamma users. ${ }^{16}$ In the current study, SCC was the most common of all malignancies of the head and neck area; it was more common in male subjects, and the mean age of patients with this condition was 56.7 years, which is in agreement with most other retrospective studies. ${ }^{3,5,13,19}$ On the other hand, the frequency of malignant lesions in the current study was higher than that reported in studies by Jones and Franklin, ${ }^{3}$ Moridani et al, ${ }^{18}$ and Mendez et al,,${ }^{19}$ in which they accounted for $5.4 \%, 2.4 \%$, and $1.9 \%$ of cases, respectively. The frequency of diagnosis of SCC $(n=46 ; 3.7 \%)$ was higher than the frequency of diagnosis of epithelial dysplasia $(n=31$; $2.5 \%$ ) in the oral cavity. This was also the case in other regions of Saudi Arabia, as only $3.6 \%$ and $2.7 \%$ of OMFPLs were dysplastic in comparison to $4.7 \%$ and $38.8 \%$ of SCC cases in both northern and south western regions, respectively. ${ }^{15,16}$ This suggests failure of early detection of suspicious oral lesions by oral health care providers, delay of case referral from general dental practitioners to biopsy the lesions, or patients being unaware of oral cancer lesions and not seeking treatment in the absence of pain. Demographic data such as socioeconomic status, location, occupation, and oral habits that can help to identify risk groups were not comprehensively recorded in the pathology reports or requisition forms. Thus, unfortunately, we were unable to evaluate these parameters in the present study. The potential value of such information with regard to understanding the characteristics of OMFL in our population should be emphasized to oral health care providers.

\section{Conclusion}

The present study yielded data on the frequency of OMFPL observed in a Saudi population presenting at an academic center in the western region of Saudi Arabia. The data constitute baseline information pertaining to epidemiologic aspects of OMFPLs that may be useful in further studies. The most commonly diagnosed OMFPLs were benign. Even when the difficulties in comparing prevalence rates from other studies are taken into account, the results of the present study are in substantial agreement with reported data in previous studies. ${ }^{5,18}$

\section{Ethics approval and consent to participate}

The study was approved by the Research Ethics Committee of the Faculty of Dentistry at King Abdulaziz University. The patient consent was waived by the Research Ethics Committee of King Abdulaziz University Hospital's Faculty of Dentistry, and all the patient data were anonymized and maintained with confidentiality.

\section{Data sharing statement}

The datasets used and/or analyzed in the current study are available from the corresponding author on reasonable request.

\section{Acknowledgments}

The authors would like to thank Wafaa Al-Qadri, Nailah Nasser, and Rayan Sharika for their help with creating the database. This study was funded by the Deanship of Scientific Research, King Abdulaziz University, Jeddah, Saudi Arabia. 


\section{Author contributions}

All authors contributed to data analysis, drafting and revising the article, gave final approval of the version to be published, and agree to be accountable for all aspects of the work.

\section{Disclosure}

The authors report no conflicts of interest in this work.

\section{References}

1. Mota-Ramírez A, Silvestre FJ, Simó JM. Oral biopsy in dental practice. Med Oral Patol Oral Cir Bucal. 2007;12(7):E504-510.

2. Gambhir RS, Veeresha KL, Sohi R, Kakkar H, Aggarwal A, Gupta D. The prevalence of oral mucosal lesions in the patients visiting a dental school in northern India in relation to sex, site and distribution: a retrospective study. J Clin Exp Dent. 2010;3(1):e10-e17.

3. Jones AV, Franklin CD. An analysis of oral and maxillofacial pathology found in adults over a 30-year period. J Oral Pathol Med. 2006;35(7): 392-401.

4. Rahman NA. Oral and maxillofacial pathologic lesion: retrospective studies on prevalence and sociodemographic features. Arch Orofac Sci. 2014;9:65-75.

5. Ali M, Sundaram D. Biopsied oral soft tissue lesions in Kuwait: a sixyear retrospective analysis. Med Princ Pract. 2012;21(6):569-575.

6. Groppi DE, Alexis CE, Sugrue CF, Bevis CC, Bhuiya TA, Crawford JM. Consolidation of the North Shore-LIJ health system anatomic pathology services: the challenge of subspecialization, operations, quality management, staffing, and education. Am J Clin Pathol. 2013;140(1):20-30.

7. Guedes MM, Albuquerque R, Monteiro M, et al. Oral soft tissue biopsies in Oporto, Portugal: an eight year retrospective analysis. J Clin Exp Dent. 2015;7(5):e640-648.

8. Al Yamani AO, Al Sebaei MO, Bassyoni LJ, Badghaish AJ, Shawly $\mathrm{HH}$. Variation of pediatric and adolescents head and neck pathology in the city of Jeddah: a retrospective analysis over 10 years. Saudi Dent J. 2011;23(4):197-200.

9. Andreasen JO, Pindborg JJ, Hjörting-Hansen E, Axéll T. Oral health care: more than caries and periodontal disease. A survey of epidemiological studies on oral disease. Int Dent J. 1986;36(4):207-214.

10. Barnes L, Eveson JW, Reichart P. eds. Pathology and Genetics of Head and Neck Tumours. Lyon, France: IARC Press; 2005. World Health Organization Classification of Tumors;9.
11. Bezroukov V. The application of the International Classification of Diseases to dentistry and stomatology. Community Dent Oral Epidemiol. 1979;7(1):21-24.

12. Luqman M, Al Shabab AZ. A 3 year study on the clinico-pathological attributes of oral lesions in Saudi patients. Int J Contemp Dent. 2012;3(1):73-76.

13. Qannam A, Bello IO. The range of diagnoses for oral soft-tissue biopsies of geriatric patients in a Saudi Arabian teaching hospital. Saudi Dent J. 2016;28(2):96-101.

14. Nartey NHO, Mosadomi HA, Gailani M. Odontogenic tumors - a retrospective study in an Arabian population. Saudi Dent J. 1992;4:p26.

15. Alanazi YM, Alrwuili MR, Latif K, Alenzi NA, Alenzi BA, Aljabab MA. A 5-years retrospective study of oral pathological lesions in 425 Saudi patients. Pak Oral Dent J. 2016;36:45-48.

16. Saleh S, Idris A, Vani N, et al. Retrospective analysis of biopsied oral and maxillofacial lesions in south-western Saudi Arabia. Saudi Med J. 2017;38(4):405-412.

17. Franklin CD, Jones AV. A survey of oral and maxillofacial pathology specimens submitted by general dental practitioners over a 30-year period. Br Dent J. 2006;200(8):447-450.

18. Moridani SG, Shaahsavari F, Adeli MB. A 7-year retrospective study of biopsied oral lesions in 460 Iranian patients. $R S B O$. 2014;11:118-124.

19. Mendez M, Carrard VC, Haas AN, et al. A 10-year study of specimens submitted to oral pathology laboratory analysis: lesion occurrence and demographic features. Braz Oral Res. 2012;26(3):235-241.

20. Kolekar SS, Chincholi T, Nangare N, Patankar R. Oral teratoma. Int $J$ Appl Basic Med Res. 2016;6(1):54-56.

21. Takagi MM, Bussamra LC, Araujo Júnior E, et al. Prenatal diagnosis of a large epignathus teratoma using two-dimensional and threedimensional ultrasound: correlation with pathological findings. Cleft Palate Craniofac J. 2014;51(3):350-353.

22. Rachidi S, Sood AJ, Patel KG, et al. Melanotic neuroectodermal tumor of infancy: a systematic review. J Oral Maxillofac Surg. 2015;73(10): 1946-1956.

23. Sangle VA, Pooja VK, Holani A, Shah N, Chaudhary M, Khanapure S. Reactive hyperplastic lesions of the oral cavity: a retrospective survey study and literature review. Indian J Dent Res. 2018;29(1):61-66.

24. Fierro-Garibay C, Almendros-Marqués N, Berini-Aytés L, Gay-Escoda C. Prevalence of biopsied oral lesions in a Department of Oral Surgery (2007-2009). J Clin Exp Dent. 2010;3:e73-e77.

25. Vani NV, Idris AM, Saleh SM, et al. Retrospective analysis of benign orofacial tumors at a tertiary referral center in Saudi Arabia. J Investig Clin Dent. 2017;8(4):e12254.
Clinical, Cosmetic and Investigational Dentistry

\section{Publish your work in this journal}

Clinical, Cosmetic and Investigational Dentistry is an international, peer-reviewed, open access, online journal focusing on the latest clinical and experimental research in dentistry with specific emphasis on cosmetic interventions. Innovative developments in dental materials, techniques and devices that improve outcomes and patient satisfac-

\section{Dovepress}

tion and preference will be highlighted. The manuscript management system is completely online and includes a very quick and fair peerreview system, which is all easy to use. Visit http://www.dovepress. com/testimonials.php to read real quotes from published authors. 